\title{
Immunity to diphtheria in a sample of the Canadian adult population
}

\author{
Louise Pelletier MD MPH${ }^{1}$, Philippe Duclos DMV PhD ${ }^{1}$, Peter Gill PhD ${ }^{2}$, Adamedia Deforest $\mathrm{PhD}^{3}$
}

\begin{abstract}
L Pelletier, P Duclos, P Gill, A Deforest. Immunity to diphtheria in a sample of the Canadian adult population. Can J Infect Dis 1998;9(6):367-371.

OBJECTIVE: To assess immunity to diphtheria in a sample of Canadian adults.

DESIGN: A seroprevalence study of a group of plasmapheresis donors was performed over a four-month period in 1996 . A convenience sample of 1619 sera was collected to obtain a good distribution by age groups and centres. The determination of diphtheria antitoxin concentrations was performed by neutralization of diphtheria toxin in cell culture. SUBJECTS: A total of 1619 plasmapheresis donors from Halifax, Quebec City, London, Calgary and Edmonton were studied.

RESULTS: Of the 1619 sera, $20.3 \%$ tested showed susceptibility to diphtheria (antitoxin concentration less than $0.01 \mathrm{IU} / \mathrm{mL}$ ). The proportion of susceptibles increased from $9.5 \%$ in subjects 30 to 39 years of age to $36.3 \%$ in those 60 years of age or more. The age group 20 to 29 years demonstrated a higher proportion of susceptibles (18.3\%) than the next age group (30 to 39 years) in four of the five centres. Significant differences in antibody levels were also observed among the centres. There was no statistically significant difference between sexes.

CONCLUSIONS: Overall, detectable antibody and presumably immunity to diphtheria in the present sample of Canadian adults is relatively good. However, reason(s) for the relatively high proportion of susceptibles in those aged 20 to 29 years of age in certain centres, as well as why Canada has not experienced any diphtheria outbreaks in the past 20 years given these susceptibility levels, should be investigated further.
\end{abstract}

Key Words: Canada, Corynebacterium diphtheriae, Diphtheria, Immunity, Serosurvey

\section{Immunité contre la diphtérie dans un échantillon de population canadienne adulte}

OBJECTIF : Mesurer l'immunité face à la diphtérie dans un échantillon de population constitué d'adultes canadiens. MODÈLE : Une étude de séroprévalence menée auprès d'un groupe de donneurs pour plasmaphérèse a été effectuée au cours d'une période de quatre mois en 1996. Un échantillon de commodité de 1619 prélèvements sériques a été recueilli afin d'obtenir une bonne distribution par groupe d'âge et par centre. La détermination des concentrations d'antitoxine diphtérique a été effectuée par neutralisation de la toxine diphtérique dans une culture cellulaire.

SUJETS : En tout, 1619 donneurs pour plasmaphérèse de Halifax, Québec, London, Calgary et Edmonton ont été étudiés. RÉSULTATS : Parmi les 1619 spécimens, 20,3\% des échantillons testés ont manifesté une sensibilité à la diphtérie (concentration d'antitoxine inférieure à $0,01 \mathrm{UI} / \mathrm{mL}$ ). La proportion d'échantillons sensibles a augmenté de $9,5 \%$, chez les sujets de 30 à 31 ans, à 36,3\% chez les sujets de 60 ans ou plus. Le groupe des 20 à 29 ans a présenté une proportion d'échantillons sensibles (18,3\%) plus forte que le groupe d'âge suivant (30 à 39 ans) dans quatre centres sur cinq. Des différences significative de taux d'anticorps ont également été observées parmi les centres. On n'a noté aucune différence statistiquement significative entre les sexes.

voir page suivante

${ }^{1}$ Division of Immunization, Bureau of Infectious Diseases, Laboratory Centre for Diseases Control, Ottawa; ${ }^{2}$ Canadian Red Cross Society, Ottawa, Ontario; ${ }^{3}$ St Christopher's Hospital for Children and Temple University School of Medicine, Philadelphia, Pennsylvania

Correspondence: Dr Louise Pelletier, Tuberculosis Prevention and Control, Room 0106B-12, Brooke Claxton Building, PL 0900B1,

Tunney's Pasture, Ottawa, Ontario K1A OL2. Telephone 613-952-6628, fax 613-946-3902, e-mail Louise_Pelletier@hc-sc.gC.ca

Received for publication October 28, 1997. Accepted April 18, 1998 
CONCLUSIONS : De façon globale, l'anticorps décelable, et présumément l'immunité, contre la diphtérie dans le présent échantillon d'adultes canadiens sont relativement bons. Par contre, il faudra approfondir la recherche pour comprendre pourquoi la proportion de sujets sensibles parmi les 20 à 29 ans est relativement élevée dans certains centres et pourquoi le Canada n'a pas été le théâtre d'épidémies de diphtérie au cours des 20 dernières années, compte tenu des taux de sensibilité.

$\mathrm{S}$ ince the introduction of diphtheria toxoid in Canada in 1926, the incidence of diphtheria has fallen dramatically to a mean of four reported cases per year in the past decade (1). However, recent outbreaks in the new independent states of the former Soviet Union have alerted the world to the potential risk of transmission from imported cases (2). In the past decade, several European countries and the United States have carried out diphtheria seroprevalence surveys of their adult populations. The results showed susceptibility levels (diphtheria antitoxin level less than $0.01 \mathrm{IU} / \mathrm{mL}$ ) varying from $20 \%$ to $50 \%$ (3-7); the exception was a recent study performed in the United States that showed that only $4 \%$ of blood donors sampled were not protected against diphtheria (8).

Current data on the immunity to diphtheria in the Canadian adult population are limited. A 1994 serosurvey carried out in a blood donation clinic in Toronto showed that $20.6 \%$ of 709 adults tested (mean age 40.5 years) had nonprotective diphtheria antitoxin levels (9). A telephone survey assessing the immunization coverage in the Canadian adult population from 1991 to 1992 revealed that an estimated 6\% (95\% CI 5\% to $7 \%$ ) of adults had received either tetanus and diphtheria toxins, or tetanus and diptheria toxins, and polio vaccine during the year before the interview (10), indicating that probably a maximum of $60 \%$ of adults are complying with the recommended booster dose of tetanus and diphtheria toxins every 10 years (11).

The objective of the present study was, therefore, to assess the immunity to diphtheria in a sample of Canadian adults, recognizing that this is a critical factor in assessing the need for developing a contingency plan for diphtheria control in Canada.

\section{SUBJECTS AND METHODS}

Study population: Immunity to diphtheria was determined in serum samples of plasmapheresis donors from the following locations: Calgary, Alberta; Edmonton, Alberta; London, Ontario; Quebec City, Quebec and Halifax, Nova Scotia. This sample was chosen for a practical reason; sera from these donors had all been tested at a central laboratory. The target number of sera to be collected was 1925, ie, 385 specimens for each of the following age groups (years): 20 to 29,30 to 39,40 to 49 , 50 to 59 , and 60 and over. Within each age group, the sample size was estimated to assess the susceptibility level to diphtheria within five absolute percentage points with $95 \%$ confidence, based on the assumption of $50 \%$ susceptibility in the population. To obtain a good distribution by age groups and centres, a nonrandom sample was selected over a four-month period in 1996. Finally, 1619 sera samples were collected and tested (Figure 1). The targeted number of donors in two of the five age groups was not reached because it was decided that the data collection would be limited to a four-month period.
While the smaller sample size did not affect the precision level of the estimate in the age group 20 to 29 years, it did decrease the precision level of the estimate in the age group 60 years and over.

No consent forms, except for donors from Quebec (as required by article 22 of the Civil Code of Quebec), were requested because the sera collected were treated in an anonymous and unlinked manner (only age and sex were provided), and the quantity of serum required was minimal (ie, $1 \mathrm{~mL}$ ), thereby, not requiring any modification to the usual procedures used for obtaining plasma from the donor population.

Diphtheria antibody determination: Diphtheria antitoxin concentrations were determined using the in vitro seroneutralization test on African green monkey kidney cells (VERO cells) described by Miyamura $(12,13)$. Diphtheria antitoxin concentrations were expressed in IU/mL; a level of less than $0.01 \mathrm{IU} / \mathrm{mL}$ was considered to indicate susceptibility to diphtheria, 0.01 to $0.09 \mathrm{IU} / \mathrm{mL}$ to provide basic protection against the toxin manifestations of diseases, and $0.1 \mathrm{IU} / \mathrm{mL}$ or more to be fully protective (14).

Statistical analysis: The statistical significance of the difference between proportions was calculated using EPI Info 6.03 software (Centers for Disease Control and Prevention, Atlanta, Georgia). The age standardization was calculated by the direct method using the age distribution of the overall sample as the reference population.

\section{RESULTS}

Of the 1619 donors tested, $20.3 \%$ ( $95 \%$ CI $18.3 \%$ to $22.2 \%$ ) were susceptible to diphtheria, $36.1 \%$ ( $95 \%$ CI $33.8 \%$ to $38.4 \%$ ) had basic protection and $43.5 \%$ (95\% CI $41.1 \%$ to $45.9 \%$ ) had full protection.

The proportion of susceptible subjects increased with age from $9.5 \%$ in the 30 to 39 years age group to $36.3 \%$ in the

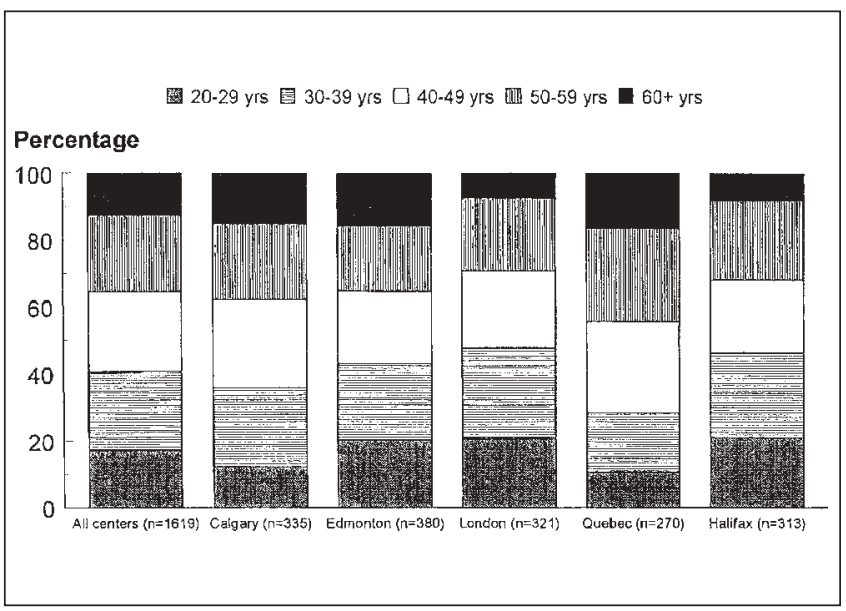

Figure 1) Distribution of sera collected by age group and centre: Plasmapheresis donors, Canada, 1996 
TABLE 1

Diphtheria immunity by age group in plasmapheresis donors, Canada, 1996

\begin{tabular}{|c|c|c|c|c|}
\hline Age group (years) & \multicolumn{4}{|c|}{ Status } \\
\hline 30-39 & 379 & $9.5(6.5-12.5)$ & $34.0(29.2-38.8)$ & $56.5(51.5-61.5)$ \\
\hline $40-49$ & 387 & $17.8(14.0-21.6)$ & $37.2(32.4-42.0)$ & $45.0(40.0-50.0)$ \\
\hline older than 60 & 204 & $36.3(29.7-42.9)$ & $34.3(27.8-40.8)$ & $29.4(23.1-35.7)$ \\
\hline Total & 1619 & $20.3(18.3-22.2)$ & $36.1(33.8-38.4)$ & 43.5 (41.1-45.9) \\
\hline
\end{tabular}

TABLE 2

Age-standardized diphtheria immunity by centre in plasmapheresis donors, Canada 1996

\begin{tabular}{|c|c|c|c|c|}
\hline \multirow[b]{2}{*}{ Centre } & \multicolumn{4}{|c|}{ Status } \\
\hline & $\begin{array}{l}\text { Number of } \\
\text { people tested }\end{array}$ & $\begin{array}{c}\text { Susceptibity }(<0.01 \mathrm{IU} / \mathrm{mL}) \\
(\%)(95 \% \mathrm{CI})\end{array}$ & $\begin{array}{l}\text { Basic protection }(0.01-0.09 \mathrm{IU} / \mathrm{mL}) \\
(\%)(95 \% \mathrm{CI})\end{array}$ & $\begin{array}{l}\text { Full protection }(\geq 0.1 \mathrm{IU} / \mathrm{mL}) \\
(\%)(95 \% \mathrm{Cl})\end{array}$ \\
\hline Calgary & 335 & $20.7(16.4-25.0)$ & $35.0(29.9-40.1)$ & $44.3(39.0-49.6)$ \\
\hline Edmonton & 380 & $20.5(16.4-25.0)$ & $33.1(28.4-37.8)$ & $46.4(41.4-51.4)$ \\
\hline London & 321 & $14.3(10.5-18.1)$ & $37.8(32.5-43.1)$ & $47.9(42.4-53.4)$ \\
\hline Quebec & 270 & $29.0(23.6-34.4)$ & $41.9(36.0-47.8)$ & $29.2(23.8-34.6$ \\
\hline Halifax & 313 & $16.4(12.3-20.5)$ & $37.2(31.8-42.6)$ & $46.5(41.0-52.0)$ \\
\hline Total & 1619 & $20.3(18.3-22.3)$ & $36.1(33.8-38.4)$ & $43.5(41.1-45.9)$ \\
\hline
\end{tabular}

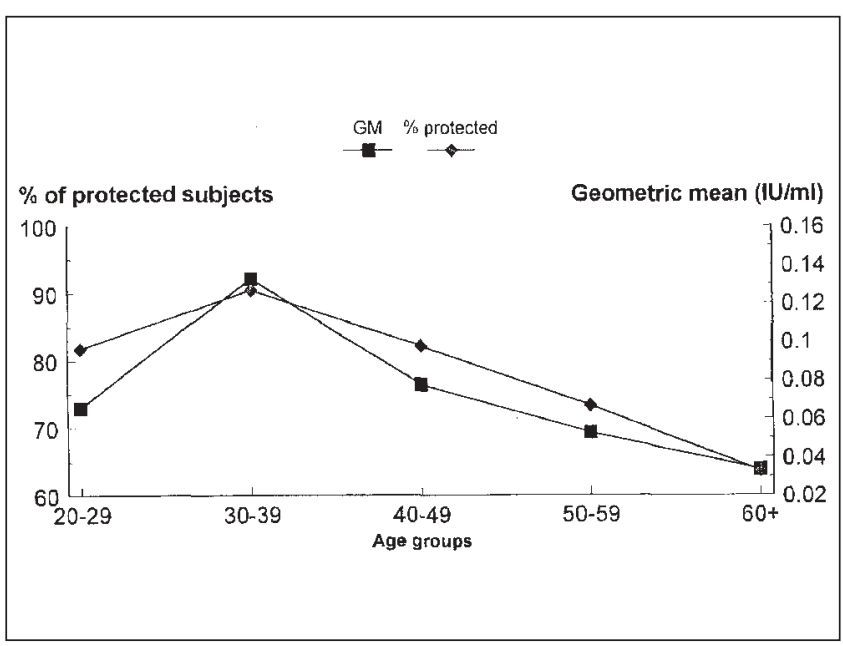

Figure 2) Proportion of protected subjects and geometric mean by age group: Plasmapheresis donors, Canada, 1996

group 60 years and over. The overall susceptibility rate for $20-$ to 29 -year-olds was $18.3 \%$ (Table 1 ). The proportion of unprotected persons in that age group was higher than that in the age group 30 to 39 years in four of the five centres and than that in the age group 40 to 49 years in three of the five centres. The mean antibody titre, expressed as geometric mean, and the prevalence of protected subjects showed the same pattern by age group (Figure 2).

There were no statistically significant differences between sexes either in the prevalence of susceptibility (males $20.8 \%$ [ $95 \%$ CI $18.5 \%$ to $23.1 \%$ ], females [ $95 \%$ CI $15.2 \%$ to $22.7 \%$ ]) or in the geometric mean of the antibody titre $(0.07 \mathrm{IU} / \mathrm{mL}$ for males and females).

After having standardized for age, statistically significant differences in immunity among the centres were still observed. The overall proportion of susceptible persons in the different study centres ranged from $14.3 \%$ to $29.0 \%$ (Table 2 ). No eastwest pattern was observed.

\section{DISCUSSION}

Overall, the immunity against diphtheria in this sample of Canadian adults is relatively good. The $20 \%$ susceptibility in adults compares well with that of adults in other industrialized countries, eg, 20\% in France (1995) (3), 26\% in Denmark (1984) (4), $28 \%$ in Italy (1985 to 1986) (5), 38\% in the United Kingdom (1993) (6) and 53\% in Poland (1986 to 1987) (7). Moreover, when comparing the level of susceptibility among this sample of Canadian adults with that of the only historical province-wide serosurvey among adults, an important reduction could be observed. The survey performed in Ontario from 1969 to 1970, in which 1229 adults (mainly women with age range 23 to 45 years) were tested, showed that $45 \%$ of them were susceptible (15). 
However, plasmapheresis donors are generally recruited from committed whole blood donors who are likely to be healthier and more health conscious than the rest of the population, possibly resulting in an underestimation of the proportion of susceptible persons. On the other hand, long term plasmapheresis may have had an impact on the level of immunoglobulins of the donors. However, regular plasmapheresis donors are checked every three months for serum total protein and electrophoretic profile of serum proteins, and those with significant abnormalities are deferred from donating. Moreover, Wasi et al (16) showed that the immunoglobulin ranges in plasmapheresis donors who had donated for more than five years did not markedly deviate from normal ranges. As well, because they came from higher socioeconomic groups and may have been less likely to have been involved in occupations or lifestyles in which there was a risk of injury, their likelihood of having received boosters as part of wound management is possibly decreased.

Variations in immunity status were observed among age groups and centres. While the National Advisory Committee on Immunization in Canada recommends that a booster dose of diphtheria toxoid be administered to adults every 10 years (11), no province has a systematic program to comply with this recommendation. Therefore, it is left to the family physicians who may be more or less committed to adult immunization programs. In fact, the administration of tetanus toxoid (combined with diphtheria toxoid) for the management of wounds in the emergency room is probably the principal way by which most adults receive their diphtheria booster doses. This was demonstrated by a telephone survey carried out in Quebec in 1996 in which $70 \%$ of the persons interviewed who stated that they had received tetanus toxoid (including $\mathrm{T}$ toxoid, tetanus and diphtheria toxins, or tetanus and diphtheria toxins and polio vaccine) said they received the toxoid during a visit to an emergency room after an injury (17). Also, the survey showed that the proportion of those who had received the tetanus toxoid (alone or combined with diphtheria toxoid) in the previous 10 years decreased with age, from $40.5 \%$ in the age group 18 to 29 years to $10.4 \%$ in the age group 65 years and older (16). The only information available on the type of tetanus toxoids (used as proxy for toxoids administered) distributed in Canada is from the main manufacturer (Pasteur Mérieux Connaught). The overall proportion of monovalent tetanus toxoid distributed in Canada has recently decreased dramatically from $21 \%$ in 1989 to $1 \%$ in 1996 . Among the provinces studied, this proportion also varied greatly from $16 \%$ in Alberta to $5 \%$ in Nova Scotia during the same period. Moreover, tetanus and diphtheria toxins, the first combination product to be used as a tetanus and diphtheria booster for adults, were licensed in Canada only in 1981. Being in contact with circulating $C$ diphtheriae is probably another way to increase diphtheria antibody levels (14). In Canada, the circulation of $C$ diphtheriae occurred for a much longer period in certain provinces. In fact, most of the cases of diphtheria reported in the last 35 years (which also included the reporting of carriers up to the early 1980s) were from Alberta, British Columbia and Manitoba (18,19, unpublished data).
The unexpectedly high proportion of susceptibles among the 20 to 29 years age group compared with the 30 to 39 years age group is surprising. Because this pattern was observed in the recent serosurvey performed in Toronto where blood donors under 30 years of age had a greater proportion of susceptibles $(17.0 \%)$ than the those 30 to 39 years of age (13.3\%) (9), our findings are unlikely to be just an artefact. This phenomenon has also been seen in Germany, Japan and Russia (20). For a few decades in Canada, most of the provinces have had a school-based booster program for adolescents 14 to 16 years of age. Although there is little information available on vaccine coverage rates, we would have expected the 20- to 29year-old population to have a higher proportion of seropositivity than that observed.

The relatively very small proportion of susceptibles in the 30 to 39 years age group probably reflects the cumulative proportion of persons who received at least a tetanus and diphtheria toxins booster dose for wound management in their young adulthood. The positive linear relationship between age and proportion of susceptibles observed in subjects 30 years old and over was expected. Because there is no systematic diphtheria immunization program for adults, the observed relationship likely reflects the trend that as a person's age increases, the less likely that person is to have been recently injured and to have received a booster dose at the emergency room, and the less likely that person is to have received a tetanus toxoid combined with diphtheria in the past. The lack of diphtheria boosters is leading to waning immunity with time.

While overall immunity levels against diphtheria are relatively good in the Canadian adults sampled, other groups in the Canadian population that may be at higher risk of developing diphtheria, such as the homeless living in poor sanitary and crowded conditions, should not be forgotten. Moreover, even in the Canadian adults sampled, there are high levels of susceptibility in certain age groups and certain centres. Because those individuals are in theory at risk for the disease and may trigger outbreaks, it is surprising that Canada has not experienced any outbreaks for many years. Some explanation can be put forward. Perhaps, it is due to the very good immunization coverage rate for diphtheria in Canadian children (21), the lack of which was, according to Galazka et al (22), the most critical factor in the resurgence of diphtheria in the Russian Federation and the Ukraine. Or, it may be that $80 \%$ of the adult population protected against diphtheria is enough to provide a good level of herd immunity. Finally, it is possible that 'susceptible' individuals have, in fact, received diphtheria toxoid in the past and experienced waning immunity but still possessed an immunological memory that could result in the boosting of antibody levels if challenged $(23,24)$.

ACKNOWLEDGEMENT: We thank the following people for their excellent work: Katerina Fowler (deceased) and Mathias Haun from the Canadian Red Cross Society for the collection of the epidemiological data and specimens, and Alicia Tortu from St Christopher's Hospital for Children for performing the antibody assays. 


\section{REFERENCES}

1. Laboratory Centre for Disease Control. Notifiable diseases annual summary, 1994. Can Commun Dis Rep 1996;22(Suppl 2):76-7.

2. Hardy IR, Dittmann S, Sutter RW. Current situation and control strategies for resurgence of diphtheria in newly independent states of the former Soviet Union. Lancet 1996;347:1739-44.

3. Vincent-Ballereau F, Schrive I, Fisch A, et al. La population francaise est-elle protégée la diphthérie en 1995? Med Mal Infect 1995;25:622-6.

4. Kjeldsen K, Simonsen O, Heron I. Immunity against diphtheria and tetanus in age group 30-70 years. Scand J Infect Dis 1988;20:177-85

5. Wirz M, Puccineli M, Mele C, Gentili G. Immunity to diphtheria in the 4-70 year age group in Italy. Vaccine 1995;13:771-3.

6. Maple PA, Efstratiou A, George RC, Andrews NJ, Sesardic D. Diphtheria immunity in UK blood donors. Lancet 1995;345:963-5

7. Galazka A, Kardymowicz B. Immunity against diphtheria in adults in Poland. Epidemiol Infect 1989;103:587-93.

8. Gupta RK, Griffin P, Xu J, Rivera R, Thompson C, Siber GR. Diphtheria antitoxin levels in US blood and plasma donors. J Infect Dis 1996;173:1493-7.

9. Yuan L, Lau W, Thipphawong J, Kasenda M, Xie F, Bevilacqua J. Diphtheria and tetanus immunity among blood donors in Toronto. Can Med Assoc J 1997;156:985-90.

10. Duclos P. Evaluation of immunization coverage in the adult population of Canada. Can J Infect Dis 1994;5:227-31.

11. National Advisory Committee on Immunization. Canadian Immunization Guide, 4th edn. Ottawa: Health Canada, 1993.

12. Miyamura K, Nishio S, Ito A, Murata R, Kono R. Micro cell culture method for determination of diphtheria toxin and antitoxin titres using VERO cells. I. Studies on factors affecting the toxin and antitoxin titration. J Biol Stand 1974;2:189-201.

13. Miyamura K, Nishi S, Ito A, Murata R, Kono R. Micro cell culture method for determination of diphtheria toxin and antitoxin titres using VERO cells. II. Comparison with the rabbit skin method and practical application for seroepidemiological studies. J Biol Stand 1974;2:203-9.

14. Expanded program on immunization. The immunological basis for immunization: Diphtheria, module 2. Geneva: World Health Organisation, 1993.

15. MacLeod DRE, Ing WK, Belcourt RJP, Pearson EW, Bell JS. Antibody status to poliomyelitis, measles, rubella, diphtheria and tetanus, Ontario, 1969-1970: deficiencies discovered and remedies required. Can Med Assoc J 1975;113:619-23.

16. Wasi S, Santowski T, Murray SA, Perrault RA, Gill P. The Canadian Red Cross plasmapheresis donor safety program: changes in plasma proteins after long-term plasmapheresis. Vox Sang 1991;60:82-7.

17. Duclos P, Arruda H, Dessau JC, et al. Immunization survey of non-institutionalized adults - Quebec. Can Comm Dis Rep 1996;22:177-81.

18. Varughese P. Diphtheria in Canada. Can Dis Wkly Rep 1978;14:65-8.

19. Bollegraph E. Diphtheria in Canada, 1977-1987. Can Dis Wkly Rep 1988;14:73-6.

20. Galazka AM, Robertson SE. Immunization against diphtheria with special emphasis on immunization of adults. Vaccine 1996;14:845-57.

21. Duclos P. Vaccination coverage of 2-year-old children and immunization practices? Canada, 1994. Vaccine 1997;15:20-4.

22. Galazka AM, Robertson SE, Oblapenko GP. Resurgence of diphtheria. Eur J Epidem 1995;11:95-105.

23. Bjorkholm B, Granstrom M, Hagberg L. Diphtheria antitoxin titres six years after basic immunization of adults. Vaccine 1996;14:1633-6.

24. Mathias RG, Schechter MT. Booster immunisation for diphtheria and tetanus: no evidence of need in adults. Lancet 1985;i:1089-91. 


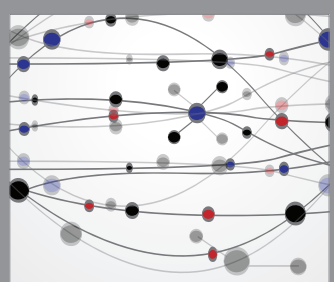

The Scientific World Journal
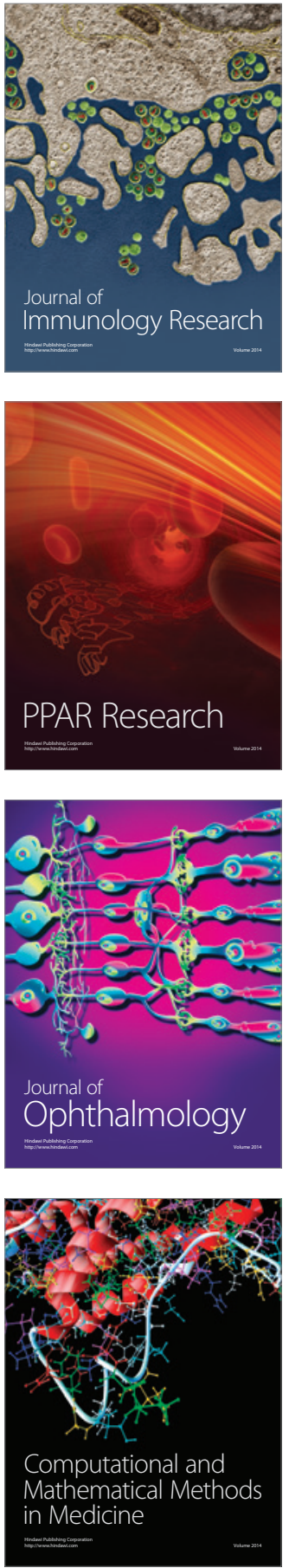

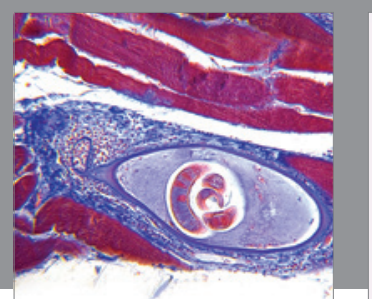

Gastroenterology Research and Practice

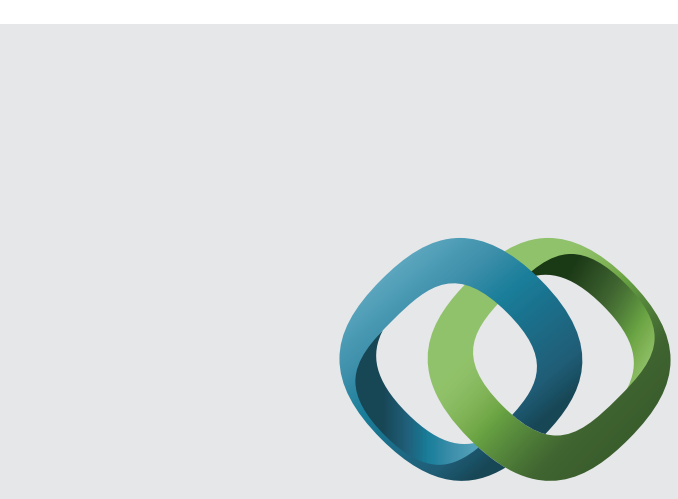

\section{Hindawi}

Submit your manuscripts at

http://www.hindawi.com
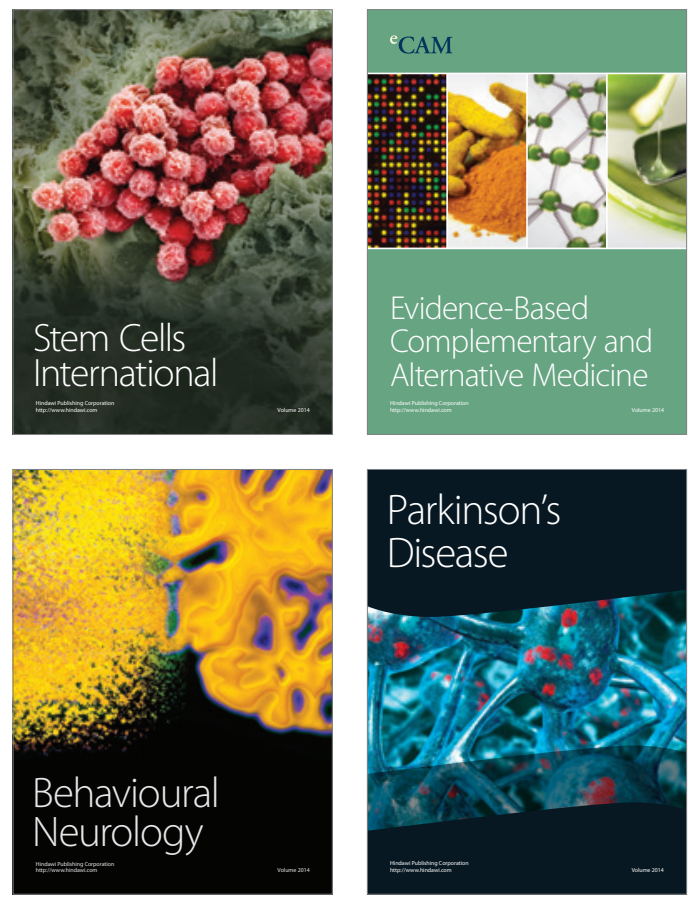
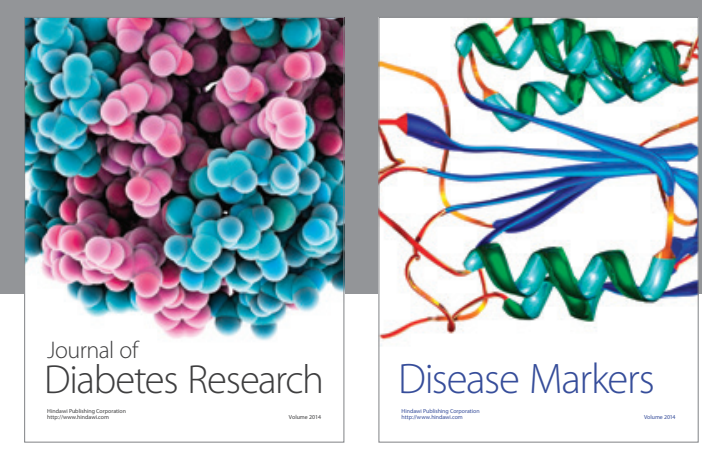

Disease Markers
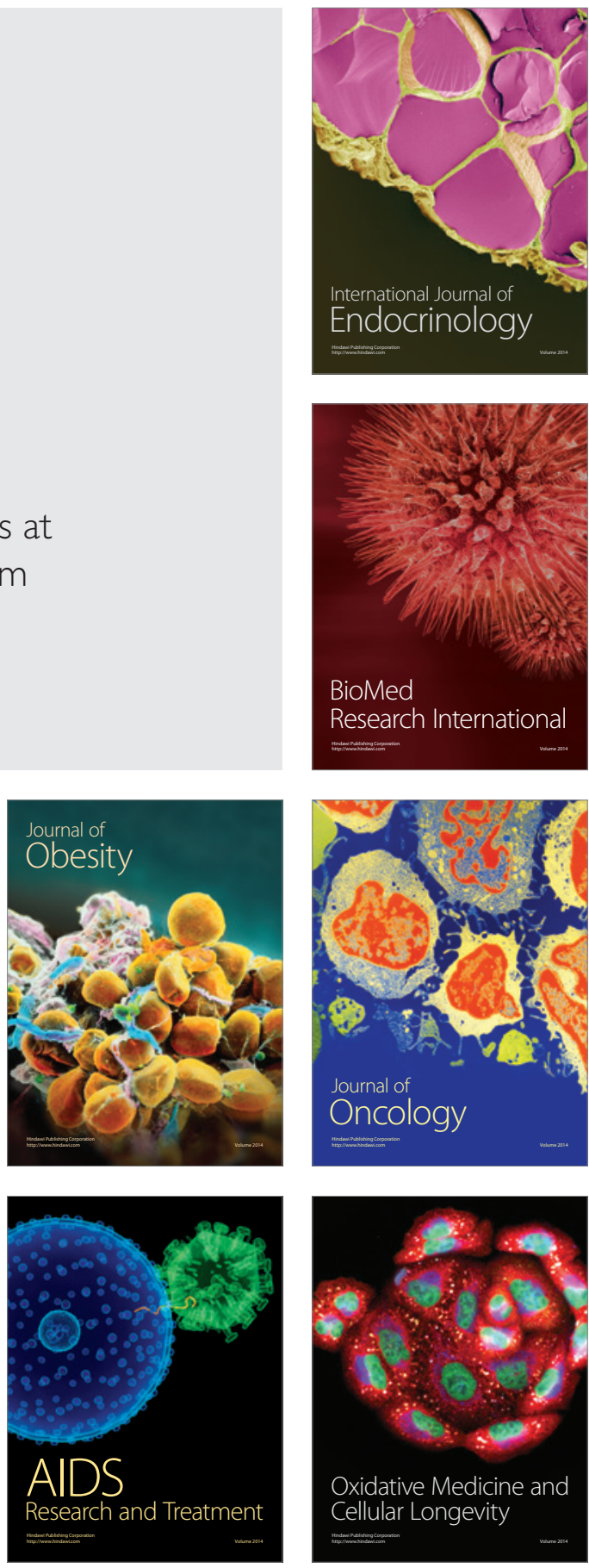